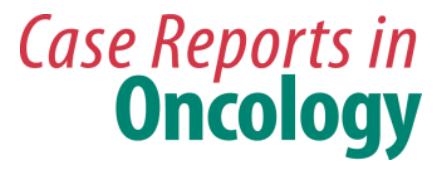

Case Rep Oncol 2017;10:638-643

DOI: $10.1159 / 000478002$

Publisned online: July 11, 2017

www.karger.com/cro

This article is licensed under the Creative Commons Attribution-NonCommercial 4.0 International License (CC BY-NC) (http://www.karger.com/Services/OpenAccessLicense). Usage and distribution for commercial purposes requires written permission.

\title{
Isolated Splenic Metastasis from Non-Small-Cell Lung Cancer: A Case Report and Review of the Literature
}

\author{
Nikolaos Mitsimponas ${ }^{a} \quad$ Maria Mitsogianni $^{a} \quad$ Felipe Crespo $^{a}$ \\ Karl-Axel Hartmann ${ }^{b}$ Stefan Diederich ${ }^{c}$ Bernd Klosterhalfen ${ }^{d}$ \\ Aristoteles Giagounidis ${ }^{a}$ \\ a Department of Oncology, Hematology and Palliative Care, Marien Hospital Düsseldorf, \\ Düsseldorf, Germany; ${ }^{b}$ Department of Radiation Therapy and Radiation Oncology, Marien \\ Hospital Düsseldorf, Düsseldorf, Germany; ${ }^{C}$ Department of Radiology, Marien Hospital \\ Düsseldorf, Düsseldorf, Germany; ${ }^{\mathrm{d}}$ Department of Pathology, Marien Hospital Düsseldorf, \\ Düsseldorf, Germany
}

\section{Keywords}

Non-small-cell lung cancer $\cdot$ Isolated splenic metastasis $\cdot$ Splenectomy

\begin{abstract}
Metastases to the spleen are rare but have been reported for different tumor entities, including breast cancer, lung cancer, colorectal cancer, ovarian cancer, and melanoma. As an isolated event, splenic metastasis from non-small-cell lung cancer (NSCLC) is exceedingly rare. Until now, only 28 cases have been reported in the medical literature. We report the case of a 66 -year-old woman with NSCLC (adenocarcinoma) who presented with a synchronous, isolated splenic metastasis. Operative removal of both primary tumor and metastasis was not possible due to multiple comorbidities. Therefore, treatment was limited to combined systemic chemotherapy and simultaneous radiation of the primary tumor, which led to partial remission of the disease. Isolated metastasis to the spleen in NSCLC has been reported only 28 times in the medical literature, most often in male patients with right-sided lung tumors, most of which were adenocarcinomas. The majority of patients were asymptomatic with respect to splenic metastasis. About half of the reported cases were isolated metachronous
\end{abstract}




\section{Case Reports in Oncology}

Case Rep Oncol 2017;10:638-643

DOI: $10.1159 / 00047800$

(C) 2017 The Author(s). Published by S. Karger AG, Base www.karger.com/cro

Report and Review of the Literature

splenic metastases. Splenectomy seems to confer a survival advantage. We review the pertinent medical literature.

(C) 2017 The Author(s)

Published by S. Karger AG, Basel

\section{Introduction}

Non-small-cell lung cancer (NSCLC) is the most common type of pulmonary cancer and accounts for $85-90 \%$ of lung cancers $[1,2]$. Histological subtypes of NSCLC are adenocarcinoma ( $50 \%$ of cases), squamous cell carcinoma ( $40 \%$ of cases), large-cell carcinoma (almost $10 \%$ of cases), and rarely adenosquamous carcinoma. The most common sites of metastasis in NSCLC are the central nervous system, bones, liver, contralateral lung, adrenal glands, and lymph nodes. Almost $50 \%$ of lung cancers are metastatic at diagnosis. Rarely, NSCLC metastases have been reported in soft tissue, kidney, peritoneum, spleen, pancreas, intestine, bone marrow, eye, ovary, thyroid, heart, breast, nasal cavity, and tonsils [3]. Generally, metastases to the spleen from solid tumors are uncommon. The prevalence of splenic metastasis ranges from 2.3 to $7.1 \%$ for all solid cancers [4]. Although splenic metastasis from breast cancer, lung cancer, colorectal cancer, ovarian cancer, and melanoma (commonest site of splenic metastases per primary tumor) have been reported [4-6], isolated splenic metastasis from lung cancer is an extremely rare complication, and, to our knowledge, only 28 cases have been reported in the medical literature. We report the case of a 66-year-old woman with a primary isolated splenic metastasis from adenocarcinoma of the lung (NSCLC).

\section{Case Presentation}

A 66-year-old woman presented in June 2016 with acute dyspnea and chest pain. A computed tomography (CT) scan revealed a right-sided lung tumor with ipsilateral enlarged mediastinal lymph nodes. Fine-needle aspiration showed moderately (G2) differentiated bronchial adenocarcinoma. A CT of the abdomen demonstrated a low-density cystic lesion in the spleen which measured $3.6 \mathrm{~cm}$ in diameter, in keeping with primary splenic metastasis. Therefore, the tumor was staged as cT2a cN2 cM1b. The primary tumor did not express EGFR or ALK mutations. The patient had several comorbidities, including chronic obstructive lung disease (Gold IV), obesity, diabetes mellitus type II, elevated blood pressure, and a recent episode of bilateral central pulmonary embolism. Operative removal of the primary tumor and synchronous or metachronous splenectomy were deemed impossible due to multiple comorbidities. We proceeded with combination chemoradiotherapy of the primary tumor using cisplatin and vinorelbine. We later substituted carboplatin for cisplatin due to renal insufficiency. In October 2016, after 6 courses of therapy, a follow-up CT scan demonstrated partial remission of the primary tumor and shrinkage of the splenic metastasis to a maximum diameter of $1.6 \mathrm{~cm}$. Further best supportive care was offered to the patient because of her severely limited overall condition. 


\section{Case Reports in Oncology}

\section{Discussion}

The reported incidence of splenic metastasis from primary lung cancer is 1.2-5.6\% [79], and in this setting, splenic metastasis is mainly seen in the terminal stage as part of a diffuse metastatic process, where an average of 3-6 other organs are usually involved [7, 10, 11]. We found only 28 cases of isolated splenic metastasis from lung cancer in the literature (Table 1). In these cases, a strong male predominance (58\%) was recorded (patients ranging in age from 49 to 82 [mean 62.3] years). In most reports, the primary tumor was located in the right lung. The most common histopathological subtype of lung cancer with isolated splenic metastasis was adenocarcinoma ( $44 \%$ of cases), followed by squamous cell cancer (17\% of cases) and large-cell lung cancer (17\% of cases). Surprisingly, there is no report of isolated splenic metastasis in small-cell lung cancer, although splenic metastasis in the context of multiple metastatic sites is well recognized in small-cell lung cancer [12-14]. One case of carcinoid with isolated spleen deposits has been reported. Including our report, splenic metastasis was synchronous in 12 cases and metachronous in another 17 cases. In the 17 cases of metachronous isolated splenic metastasis, the median interval between the diagnosis of the primary tumor and isolated splenic metastasis was 22.2 (range 2-96) months. The majority of cases were asymptomatic ( $62 \%$ of cases), and the diagnosis was serendipitously made at follow-up exams. Some patients presented with splenic rupture (12\% of cases), abdominal pain $(21 \%$ of cases), and fever ( $3 \%$ of cases).

The early detection of metastasis to the spleen is challenging, since most cases of splenic metastasis are asymptomatic, and most of them are detected incidentally. CT scan of the abdomen remains the gold standard to detect splenic metastasis, including in the case of primary lung cancer. Some studies have also mentioned the significance of FDG-PET/CT in the detection of splenic metastasis from lung cancer [4, 6, 15-17]. By CT imaging, splenic metastases can appear in 3 patterns: (1) as a solid lesion, (2) as a cystic lesion (as in our case), and (3) as a solid-cystic lesion [7]. In histopathology, splenic metastases appear in 3 macroscopic patterns: macronodular, micronodular, and diffuse [6]. Iguchi et al. [14] mentioned that the micronodular and diffuse type might not be detectable on abdominal CT scan, although FDG-PET/CT may detect the diffuse type of splenic metastasis. In case of a macronodular pattern, the metastasis can either present as solitary or multiple nodules; the micronodular pattern can be diagnosed by the presence of scattered uniform miliary nodules, and in case of a diffuse pattern, the splenic parenchyma is completely occupied by tumor cells [7]. The rarity of splenic metastases could be explained by anatomic factors and the high-quality immunological equipment of the spleen, which ensures an inhibitory effect on the growth of metastatic cells [5]. The differential diagnosis of a splenic mass includes splenic metastasis, hemangioma, hamartoma, non-Hodgkin lymphoma, Hodgkin lymphoma, sarcoidosis, tuberculosis, and histoplasmosis [6].

The majority of patients underwent a surgical resection of the primary tumor $(65 \%$ of cases). In most cases, the patients underwent a splenectomy (83\% of cases). Considering the therapeutic principle of oligometastatic disease for solitary brain or adrenal metastasis, splenectomy should be considered a therapeutic option for these patients. Systemic chemotherapy after splenectomy or after double surgical resection (splenectomy followed by resection of the lung lesion or vice versa) can be considered since it can provide a prolonged progression-free survival and overall survival [4]. The vast majority of patients died 1-49 


\section{Case Reports in Oncology}

months after splenectomy, with rare cases of prolonged survival up to 96 months, as reported by Sardenberg et al. [6].

\section{Statement of Ethics}

The authors have no ethical conflicts to disclose.

\section{Disclosure Statement}

The authors have no conflicts of interest to declare.

\section{References}

1 Novello S, Barlesi F, Califano R, Cufer T, Ekman S, Giaj Levra M, Kerr K, Popat S, Reck M, Senan S, Simo GV, Vansteenkiste J, Peters S; ESMO Guidelines Committee: Metastatic non-small-cell lung cancer: ESMO Clinical Practice Guidelines for diagnosis, treatment and follow-up. Ann Oncol 2016;27(suppl 5):v1v27.

2 Jemal A, Bray F, Center MM, et al: Global cancer statistics. CA Cancer J Clin 2011;61:69-90.

-3 Niu FY, et al: Distribution and prognosis of uncommon metastases from non-small cell lung cancer. BMC Cancer 2016;16:149.

4 Tang H, Huang H, Xiu Q, Shi Z: Isolated splenic metastasis from lung cancer: ringleader of continuous fever. Eur Respir Rev 2010;19:253-256.

5 Compérat E, Bardier-Dupas A, Camparo P, Capron F, Charlotte F: Splenic metastases: clinicopathologic presentation, differential diagnosis, and pathogenesis. Arch Pathol Lab Med 2007;131:965-969. Sardenberg RA, Pinto C, Bueno CA, Younes RN: Non-small cell lung cancer stage IV long-term survival with isolated spleen metastasis. Ann Thorac Surg 2013;95:1432-1434.

7 Cai Q, Kragel P: Isolated splenic metastasis in a patient with lung carcinoma: case report and review of the literature. J Clin Exp Pathol 2015;5:252.

-8 Satoh H, Watanabe K, Ishikawa H, Yamashita YT, Ohtsuka M, et al: Splenic metastasis of lung cancer. Oncol Rep 2001;8:1239-1241.

9 Kinoshita A, Nakano M, Fukuda M, Kasai T, Suyama N, et al: Splenic metastasis from lung cancer. Neth J Med 1995;47:219-223.

10 Berge T: Splenic metastases. Frequencies and patterns. Acta Pathol Microbiol Scand A 1974;82:499_ 506.

11 Schon CA, Gorg C, Ramaswamy A, Barth PJ: Splenic metastases in a large unselected autopsy series. Pathol Res Pract 2006;202:351-356.

-12 Auerbach 0, Garfinkel L, Parks VR: Histologic type of lung cancer in relation to smoking habits, year of diagnosis and sites of metastases. Chest 1975;67:382-387.

13 Densert 0, Söderström J: Diffuse metastases in bronchial cancer. Acta Pathol Microbiol Scand 1965;64:477-484.

14 Iguchi K, Ishibashi O, Kondo T, Kagohashi K, Takayashiki N, Satoh H: Isolated spleen recurrence in a patient with lung adenocarcinoma: a case report. Exp Ther Med 2015;10:733-736.

15 Yen RF, Wu YW, Pan MH, Tzen KY: Early detection of splenic metastasis of lung cancer by 18F-2-fluoro2-deoxyglucose positron emission tomography. J Formos Med Assoc 2005;104:674-676. Fujii M, Tanaka H, Sawazumi T, et al: A case of solitary splenic metastasis following operation for pulmonary pleomorphic carcinoma: detected at an early stage by FDG-PET. Nihon Kokyuki Gakkai Zasshi 2008;46:950-954.

17 Soussan M, Pop G, Ouvrier MJ, Neuman A, Weinmann P: Diagnosis of synchronous isolated splenic metastasis from lung adenocarcinoma: complementary role of FDG PET/CT and diffusion-weighted MRI. Clin Nucl Med 2011;36:707-709. 


\section{Case Reports in Oncology}

Klein B, Stein M, Kuten A, Steiner M, Barshalom D, Robinson E, Gal D: Splenomegaly and solitary spleen metastasis in solid tumors. Cancer 1987;60:100-102.

19 Edelman AS, Rotterdam H: Solitary splenic metastasis of an adenocarcinoma of the lung. Am J Clin Pathol 1990;94:326-328.

20 Macheers SK, Mansour KA: Management of isolated splenic metastases from carcinoma of the lung: a case report and review of the literature. Am Surg 1992;58:683-685. Gupta PB, Harvey L: Spontaneous rupture of the spleen secondary to metastatic carcinoma. Br J Surg 1993;80:613.

-22 Takada T, Takami H: Solitary splenic metastasis of a carcinoid tumor of the lung eight years postoperatively. J Surg Oncol 1998;67:47-48.

-23 Tomaszewski D, Bereza S, Sternau A: Solitary splenic metastases from lung cancer - one-time surgical procedure (in Polish). Pneumonol Alergol Pol 2003;71:533-537.

24 Massarweh S, Dhingra H: Unusual sites of malignancy: case 3. Solitary splenic metastasis in lung can cer with spontaneous rupture. J Clin Oncol 2001;19:1574-1575. Schmidt BJ, Smith SL: Isolated splenic metastasis from primary lung adenocarcinoma. South Med J 2004;97:298-300.

-26 Pramesh CS, Prabhudesai SG, Parasnis AS, Mistry RC, Sharma S: Isolated splenic metastasis from non small cell lung cancer. Ann Thorac Cardiovasc Surg 2004;10:247-248.

27 Lachachi F, Abita T, Durand Fontanier S, Maisonnette F, Descottes B: Spontaneous splenic rupture due to splenic metastasis of lung cancer. Ann Chir 2004;129:521-522.

-28 Sánchez-Romero A, Oliver I, Costa D, Orduña A, Lacueva J, Pérez-Vicente F, Arroyo A, Calpena R: Giant splenic metastasis due to lung adenocarcinoma. Clin Transl Oncol 2006;8:294-295.

29 Van Hul I, Cools P, Rutsaert R: Solitary splenic metastasis of an adenocarcinoma of the lung 2 years postoperatively. Acta Chir Belg 2008;108:462-463.

-30 Ando K, Kaneko N, Yi L, Sato C, Yasui D, Inoue K, Misawa M, Ohkuni Y: Splenic metastasis of lung cancer. Nihon Kokyuki Gakkai Zasshi 2009;47:581-584.

-31 Chloros D, Bitzikas G, Kakoura M, Chatzikostas G, Makridis C, Tsitouridis I: Solitary splenic metastasis of squamous lung cancer: a case report. Cases J 2009;2:9091.

-32 Dias AR, Pinto RA, Ravanini JN, Lupinacci RM, Cecconello I, Ribeiro U Jr: Isolated splenic metastasis from lung squamous cell carcinoma. World J Surg Oncol 2012;10:24.

33 Assouline P, Leger-Ravet MB, Paquet JC, Kardache M, Decoux L, Kettaneh L, Faucher JN, Oliviero G: Splenic metastasis from a bronchial carcinoma. Rev Mal Respir 2006;23(3 Pt 1):265-268.

-34 Scintu F, Carta M, Frau G, Marongiu L, Pipia G, Casula G: Splenic metastases of pulmonary carcinoma. Apropos of a clinical case. Minerva Chir 1991;46:1277-1280.

-35 Oussama B, Makrem M, Neji FM, Amine L, Brahim K, Karim S, Sami B: Non-small cell lung cancer revealed by a solitary splenic metastasis of lung cancer. Tunis Med 2013;91:484-485.

-36 Eisa N, Alhafez B, Alraiyes AH, Alraies MC: Abdominal pain as initial presentation of lung cancer. BMJ Case Rep 2014, DOI: 10.1136/bcr-2013-200613.

37 Belli A, De Luca G, Bianco F, De Franciscis S, Tatangelo F, Romano GM, Rocco G: An unusual metastatic site for primary lung cancer: the spleen. J Thorac Oncol 2016;11:128-129. 
Table 1. Isolated splenic metastasis from lung cancer

\begin{tabular}{|c|c|c|c|c|c|c|c|c|c|}
\hline First author [ref.] & $\begin{array}{l}\text { Histology (primary lung } \\
\text { lesion) }\end{array}$ & $\begin{array}{l}\text { Lung } \\
\text { lesion } \\
\text { side }\end{array}$ & $\begin{array}{l}\text { Time to } \\
\text { splenic metas- } \\
\text { tasis }\end{array}$ & Sex & $\begin{array}{l}\text { Age, } \\
\text { years }\end{array}$ & $\begin{array}{l}\text { Metastasis } \\
\text { symptoms }\end{array}$ & Treatment of primary tumor & $\begin{array}{l}\text { Treatment of splenic } \\
\text { metastasis }\end{array}$ & $\begin{array}{l}\text { Follow-up at the time } \\
\text { of the report }\end{array}$ \\
\hline Klein [18] & Bronchioalveolar carcinoma & Right & 20 months & $\mathrm{F}$ & 57 & Abdominal pain & $\begin{array}{l}\text { Right lower and middle } \\
\text { lobectomy }\end{array}$ & Splenectomy & $\begin{array}{l}\text { Died } 49 \text { months after } \\
\text { splenectomy }\end{array}$ \\
\hline Edelman [19] & $\begin{array}{l}\text { Poorly differentiated } \\
\text { adenocarcinoma }\end{array}$ & Left & 0 months & $\mathrm{F}$ & 63 & Asymptomatic & n.a. & n.a. & n.a. \\
\hline Macheers [20] & $\begin{array}{l}\text { Large-cell undifferentiated } \\
\text { carcinoma }\end{array}$ & Left & 0 months & n.a. & n.a. & Asymptomatic & n.a. & Splenectomy & $\begin{array}{l}\text { Died } 1 \text { month after } \\
\text { splenectomy }\end{array}$ \\
\hline Gupta [21] & Squamous cell carcinoma & Right & 0 months & n.a. & n.a. & Splenic rupture & n.a. & Splenectomy & $\begin{array}{l}\text { Died } 8 \text { weeks after } \\
\text { splenectomy }\end{array}$ \\
\hline Kinoshita [9] & Squamous cell carcinoma & Left & 14 months & $\mathrm{M}$ & 72 & Asymptomatic & $\begin{array}{l}\text { Surgical removal of primary } \\
\text { tumor }\end{array}$ & Splenectomy & $\begin{array}{l}\text { Died } 27 \text { months after } \\
\text { splenectomy }\end{array}$ \\
\hline Takada [22] & $\begin{array}{l}\text { Bronchopulmonary carcinoid } \\
\text { tumor }\end{array}$ & Right & 96 months & $\mathrm{M}$ & 49 & Abdominal pain & Right upper lobectomy & Splenectomy & $\begin{array}{l}\text { Disease free after } \\
8 \text { years }\end{array}$ \\
\hline Tomaszewski [23] & Lung cancer & Left & 0 months & $\mathrm{M}$ & 68 & Asymptomatic & Upper left lobectomy & Splenectomy & n.a. \\
\hline Massarweh [24] & $\begin{array}{l}\text { Poorly differentiated } \\
\text { adenocarcinoma }\end{array}$ & Left & 0 months & $\mathrm{M}$ & 68 & Splenic rupture & Palliative chemotherapy & Splenectomy & n.a. \\
\hline Schmidt [25] & $\begin{array}{l}\text { Moderately differentiated } \\
\text { adenocarcinoma }\end{array}$ & Left & 25 months & $\mathrm{M}$ & 72 & Asymptomatic & $\begin{array}{l}\text { Surgical removal of primary } \\
\text { tumor }\end{array}$ & n.a. & $\begin{array}{l}\text { Disease free after } \\
2 \text { years }\end{array}$ \\
\hline Pramesh [26] & Squamous cell carcinoma & Left & 2 months & $\mathrm{M}$ & 55 & Asymptomatic & Combined radiochemotherapy & $\begin{array}{l}\text { Palliative } \\
\text { chemotherapy }\end{array}$ & n.a. \\
\hline$\overline{\text { Lachachi [27] }}$ & $\begin{array}{l}\text { Poorly differentiated } \\
\text { carcinoma }\end{array}$ & Right & 0 months & n.a. & n.a. & Splenic rupture & n.a. & Splenectomy & n.a. \\
\hline$\overline{\text { Sánchez-Romero [28] }}$ & ]Adenocarcinoma & Left & 0 months & $\mathrm{M}$ & 73 & Abdominal pain & Left lung resection & Splenectomy & n.a. \\
\hline$\overline{\text { Van Hul [29] }}$ & Adenocarcinoma & Left & 24 months & $\mathrm{M}$ & 67 & Asymptomatic & $\begin{array}{l}\text { Surgical removal of primary } \\
\text { tumor }\end{array}$ & Splenectomy & n.a. \\
\hline Ando [30] & Squamous cell carcinoma & Right & 10 months & $\mathrm{M}$ & 71 & Asymptomatic & Combined radiochemotherapy & Splenectomy & n.a. \\
\hline$\overline{\text { Chloros [31] }}$ & Squamous cell carcinoma & Right & 0 months & $\mathrm{M}$ & 59 & Asymptomatic & $\begin{array}{l}\text { Surgical removal of primary } \\
\text { tumor }\end{array}$ & Splenectomy & n.a. \\
\hline Tang [4] & $\begin{array}{l}\text { Large-cell undifferentiated } \\
\text { carcinoma }\end{array}$ & Right & 4 months & $\mathrm{F}$ & 49 & Fever & $\begin{array}{l}\text { Lobectomy of the right middle } \\
\text { and lower lobe }\end{array}$ & Splenectomy & n.a. \\
\hline$\overline{\text { Scnitu [34] }}$ & $\begin{array}{l}\text { Large-cell anaplastic } \\
\text { carcinoma }\end{array}$ & n.a. & 0 months & n.a. & n.a. & Asymptomatic & Pulmonary lobectomy & Splenectomy & $\begin{array}{l}\text { Disease free after } \\
41 \text { months }\end{array}$ \\
\hline Yen [15] & Adenocarcinoma & Left & 24 months & $\mathrm{M}$ & 56 & Asymptomatic & Left pneumonectomy & Splenectomy & n.a. \\
\hline$\overline{\text { Fujii [16] }}$ & $\begin{array}{l}\text { Poorly differentiated } \\
\text { adenocarcinoma }\end{array}$ & Left & 3 months & $\mathrm{M}$ & 58 & Asymptomatic & Left upper lobectomy & Splenectomy & n.a. \\
\hline Assouline [33] & $\begin{array}{l}\text { Large-cell undifferentiated } \\
\text { carcinoma }\end{array}$ & Right & 21 months & $\mathrm{M}$ & 77 & Abdominal pain & Right pneumonectomy & Splenectomy & $\begin{array}{l}\text { Disease free after } \\
2 \text { years }\end{array}$ \\
\hline Oussama [35] & $\begin{array}{l}\text { Non-small-cell lung cancer, } \\
\text { further histology n.a. }\end{array}$ & Left & 0 months & $\mathrm{M}$ & 58 & Abdominal pain & Chemotherapy & Splenectomy & n.a. \\
\hline$\overline{\text { Eisa [36] }}$ & Adenocarcinoma & Right & 0 months & $\mathrm{F}$ & 53 & Abdominal pain & $\begin{array}{l}\text { Surgical removal of primary } \\
\text { tumor }\end{array}$ & Splenectomy & $\begin{array}{l}\text { Disease free at the } \\
\text { time of the report }\end{array}$ \\
\hline Belli [37] & Large-cell carcinoma & Right & 60 months & $\mathrm{M}$ & 65 & Asymptomatic & Right pneumonectomy & n.a. & n.a. \\
\hline Sardenberg [6] & Adenocarcinoma & Right & 7 months & $\mathrm{F}$ & 49 & Abdominal pain & Right upper lobectomy & Splenectomy & $\begin{array}{l}\text { Disease free after } \\
96 \text { months }\end{array}$ \\
\hline Dias [32] & Squamous cell carcinoma & Right & 16 months & $\mathrm{M}$ & 82 & Asymptomatic & Right bilobectomy & Splenectomy & $\begin{array}{l}\text { Disease free after } \\
12 \text { months }\end{array}$ \\
\hline$\overline{\text { Cai [7] }}$ & Adenocarcinoma & Right & 17 months & $\mathrm{F}$ & 56 & Asymptomatic & Right lower lobectomy & Splenectomy & n.a. \\
\hline Soussan [17] & Adenocarcinoma & n.a. & 0 months & $\mathrm{M}$ & 52 & Asymptomatic & n.a. & n.a. & n.a. \\
\hline Iguchi [14] & Adenocarcinoma & Left & 12 months & $\mathrm{F}$ & 63 & Asymptomatic & Left lower lobectomy & Splenectomy & n.a. \\
\hline Present report & Adenocarcinoma & Right & 0 months & $\mathrm{F}$ & 66 & Asymptomatic & Combined radiochemotherapy & Chemotherapy & $\begin{array}{l}\text { Still alive at the time } \\
\text { of the report }\end{array}$ \\
\hline
\end{tabular}

